\title{
Interim modelling analysis to validate reported increases in condom use and assess HIV infections averted among female sex workers and clients in southern India following a targeted HIV prevention programme
}

\author{
Michael Pickles, ${ }^{1,2}$ Anna M Foss, ${ }^{2}$ Peter Vickerman, ${ }^{2}$ Kathleen Deering, ${ }^{3}$ \\ Supriya Verma, ${ }^{4}$ Eric Demers, ${ }^{5}$ Reynold Washington, ${ }^{4,6,7}$ BM Ramesh, ${ }^{4,7}$ \\ Stephen Moses, ${ }^{7,8}$ Jamie Blanchard, ${ }^{7}$ Catherine M Lowndes, ${ }^{2,5,9}$ Michel Alary, ${ }^{5}$ \\ Sushena Reza-Paul, ${ }^{7}$ Marie-Claude Boily ${ }^{1}$
}

- Supplementary figures, tables and appendix are published online only at http://sti.bmj.com/ content/vol86/issue1

1 Department of Infectious Disease Epidemiology, Imperial College, London, UK ${ }^{2}$ Health Policy Unit, London School of Hygiene and Tropical Medicine, London, UK ${ }^{3}$ School of Population and Public Health, University of British Columbia, Vancouver, Canada ${ }^{4}$ Karnataka Health Promotion Trust, Bangalore, India ${ }^{5}$ Centre Hospitalier Affilié Universitaire de Québec, Québec, Canada ${ }^{6}$ St. John's Medical College and Hospital, Bangalore, India ${ }^{7}$ Department of Community Health Sciences, University of Manitoba, Winnipeg, Canada ${ }^{8}$ Department of Medical Microbiology, University of Manitoba, Winnipeg, Canada ${ }^{9}$ Health Protection Agency, London, UK

\section{Correspondence to}

Michael Pickles, Imperial College St Mary's Campus, Praed Street, London W2 1PG, UK; m.pickles@imperial.ac.uk

Accepted 14 November 2009

\section{ABSTRACT}

Objectives This study assesses whether the observed declines in HIV prevalence since the beginning of the 'Avahan' India HIV/AIDS prevention initiative are consistent with self-reported increases in condom use by female sex workers (FSWs) in two districts of southern India, and provides estimates of the fraction of new infections averted among FSWs and clients due to increases in condom use in commercial sex after 2004. Methods A deterministic compartmental model of HIV/sexually transmitted infection (STI) transmission incorporating heterogeneous sexual behaviour was developed, parameterised and fitted using data from two districts in Karnataka, India. Three hypotheses of condom use among FSWs were tested: $\left(\mathrm{H}_{0}\right)$, that condom use increased in line with reported FSW survey data prior to the Avahan initiative but remained constant afterwards; $\left(\mathrm{H}_{1}\right)$ that condom use increased following the Avahan initiative, in accordance with survey data; $\left(\mathrm{H}_{2}\right)$ that condom use increased according to estimates derived from condom distribution data. The proportion of fits to HIV/STI prevalence data was examined to determine which hypothesis was most consistent.

Results For Mysore 0/36/82.7 fits were identified per million parameter sets explored under hypothesis $\mathrm{H}_{0} / \mathrm{H}_{1} /$ $\mathrm{H}_{2}$, respectively, while for Belgaum 9.7/8.3/0 fits were identified. The HIV epidemics in Belgaum and Mysore are both declining. In Mysore, increases in condom use during commercial sex between 2004 and 2009 may have averted $31.2 \%$ to $47.4 \%$ of new HIV infections in FSWs, while in Belgaum it may have averted $24.8 \%$ to $43.2 \%$, if there was an increase in condom use.

Discussion Increased condom use following the Avahan intervention is likely to have played a role in curbing the HIV epidemic in Mysore. In Belgaum, given the limitations in available data, this method cannot be used alone to decide if there has been an increase in condom use.

\section{INTRODUCTION}

Karnataka, in southern India, has one of the highest prevalences of HIV among Indian states, ${ }^{1}$ and is among the states included in the 'Avahan' India HIV/ AIDS initiative established by the Bill \& Melinda Gates Foundation in 2004. Working through state- level partners and local non-governmental organisations (NGOs), the initiative is a multifaceted HIV preventive intervention promoting prevention strategies among high-risk groups, including distribution of condoms to and promotion of condom use among female sex workers (FSWs). ${ }^{2-4}$

Assessing the impact of the Avahan intervention is crucial, not only to ensure that Avahan achieves its goals of reducing HIV transmission in India, but also to inform future large-scale interventions. ${ }^{5}$ However, the dynamics of an HIV epidemic are complicated: declines in HIV prevalence can occur without any intervention effects, due to natural infection dynamics and, conversely, increases can occur even in the presence of an effective intervention. ${ }^{6}$ In order to separate out the impact of the Avahan initiative from natural HIV transmission dynamics, and because of the difficulty and huge expense of implementing community randomised controlled trials, a tailor-made transmission dynamics model will be used as one important component of the impact assessment, the framework for which is described in Boily et al. ${ }^{8}$

The final impact and cost effectiveness analysis, planned for 2011, will estimate the impact of the Avahan initiative on the HIV and sexually transmitted infection (STI) epidemics among high-risk groups and the broader population across more than 30 intervention sites. ${ }^{5}$ This paper presents the results of an interim analysis focusing on FSWs and their clients in two districts where sufficient data are currently available, and which represent different HIV/STI epidemic trends and behavioural profiles: Belgaum Urban, a higher prevalence district in which Avahan was not the first but is now the only intervention; and Mysore Urban, a lower prevalence district in which Avahan was the first and remains the only intervention.

The objective of this analysis is to determine whether the observed changes in HIV prevalence among FSWs could be solely due to natural disease dynamics rather than to a change in condom use following the intervention. We address this question by testing whether the null hypothesis $\left(\mathrm{H}_{0}\right)$ of stable (ie, no increase in) condom use following the initiation of the Avahan intervention in 2004 is less 
likely than the alternative hypotheses $\left(\mathrm{H}_{1}\right)$ that condom use actually increased by as much as reported in FSW survey data, or $\left(\mathrm{H}_{2}\right)$ that there was a lower level of preintervention condom use and a sharper postintervention increase than indicated by FSW survey data, as suggested by records of condom availability. ${ }^{9}$

\section{METHODS}

In order to model the HIV/STI epidemics in urban Belgaum and Mysore districts, an in-depth mathematical modelling analysis was undertaken with the key elements described below.

\section{Methodological framework of evaluation}

The structure of the evaluation follows the methodological framework designed and described in Boily et al. ${ }^{8}$ In short, a mathematical model was used within a Bayesian framework, where available data were first used to specify what was known about each model parameter by defining a plausible range of values (the 'prior distribution'). This distribution was then randomly sampled repeatedly, to test the model with a large number of parameter combinations and identify those parameter sets (the 'posterior distribution') that agreed with the empirical HIV/STI prevalence data shown in table 1.

One of the advantages of this approach is that the percentage of parameter sets producing a model fit to the prevalence data gives a measure of how compatible the prior parameter sets were with the observed prevalence data for the specified model. This approach was used here to test the three hypotheses described above concerning possible trends in condom use before and after the Avahan intervention. Finally, the posterior distribution was used to simulate a control group without the intervention, which was then compared to the original scenario to produce estimates of intervention impact.

\section{Model structure and parameterisation}

A purpose-built deterministic compartmental model of HIV, herpes simplex virus (HSV)-2 and syphilis transmission was constructed and parameterised to incorporate key aspects and heterogeneities of the complex FSW and client structure specific to each setting. ${ }^{10}$ In summary, the model consisted of an open

Table $1 \mathrm{HIV} /$ sexually transmitted infection (STI) prevalence data from integrated behavioural and biological assessment (IBBA) surveys in Belgaum and Mysore used to fit (FSW IBBA rounds 1 and 2, and client IBBA round 1 ) and validate (FSW IBBA rounds 2 and 3 ) the model

\begin{tabular}{|c|c|c|c|c|}
\hline \multirow[b]{2}{*}{ Survey } & \multirow{2}{*}{$\begin{array}{l}\text { District and date } \\
\text { carried out }\end{array}$} & \multicolumn{3}{|c|}{$\mathrm{Cl}$ for prevalence } \\
\hline & & HIV & HSV-2 & Syphilis \\
\hline \multicolumn{5}{|l|}{ Fitting data } \\
\hline \multirow[t]{2}{*}{$\begin{array}{l}\text { FSW IBBA } \\
\text { round } 1\end{array}$} & $\begin{array}{l}\text { Mysore } \\
\text { (August 2004) }\end{array}$ & $21.9 \%$ to $30.3 \%$ & $59.6 \%$ to $69.1 \%$ & $21.0 \%$ to $29.0 \%$ \\
\hline & $\begin{array}{l}\text { Belgaum } \\
\text { (October 2005) }\end{array}$ & $27.6 \%$ to $40.2 \%$ & $78.6 \%$ to $89.1 \%$ & $3.0 \%$ to $13.0 \%$ \\
\hline \multicolumn{5}{|c|}{ Client IBBA } \\
\hline \multirow[t]{2}{*}{ Round 1} & $\begin{array}{l}\text { Mysore } \\
\text { (October 2008) }\end{array}$ & $3.2 \%$ to $7.6 \%$ & $8.0 \%$ to $33.0 \%$ & $1.3 \%$ to $4.6 \%$ \\
\hline & $\begin{array}{l}\text { Belgaum } \\
\text { (October 2007) }\end{array}$ & $3.6 \%$ to $8.8 \%$ & $23.3 \%$ to $32.3 \%$ & $2.0 \%$ to $6.5 \%$ \\
\hline \multicolumn{5}{|c|}{ Crossvalidation and fitting data } \\
\hline \multirow[t]{2}{*}{$\begin{array}{l}\text { FSW IBBA } \\
\text { round } 2\end{array}$} & $\begin{array}{l}\text { Mysore } \\
\text { (December 2006) }\end{array}$ & $19.1 \%$ to $29.5 \%$ & & \\
\hline & $\begin{array}{l}\text { Belgaum } \\
\text { (July 2008) }\end{array}$ & $22.2 \%$ to $32.5 \%$ & & \\
\hline \multicolumn{5}{|c|}{ Crossvalidation data } \\
\hline $\begin{array}{l}\text { FSW IBBA } \\
\text { round } 3\end{array}$ & $\begin{array}{l}\text { Mysore } \\
\text { (April 2009) }\end{array}$ & $8.11 \%$ to $14.1 \%$ & & \\
\hline
\end{tabular}

FSW, female sex worker; HSV, herpes simplex virus. population, growing at the rate described by census data, ${ }^{11}$ stratified into 'high-risk' (FSWs and their clients) and 'low-risk' (the remaining population) groups. Based on work by Vickerman et al ${ }^{4}$ (see page 33), it was assumed in this model that there is no transmission between low-risk individuals. The high-risk groups (FSWs and their clients) were further stratified by variables showing strong associations with HIV prevalence and high-risk behaviour in analyses of data from serial cross-sectional surveys termed integrated behavioural and biological assessments (IBBAs). ${ }^{10} 12$

The model simulates the transmission of HIV/STIs between FSWs and their clients through commercial and longer-term non-commercial partnerships, and the bridging infections from clients to low-risk women through their non-commercial partnerships, as shown in figure 1. The force of infection depends on the disease-specific infectivity, type and duration of partnership, frequency of sex acts for the type of partnership, condom use and STI coinfection status of both partners. The three parameters influencing HIV prevalence the most in a sensitivity analysis of a representative sample of the unrestricted model runs were the number of sex acts per partnership between FSWs and occasional clients, the male to female HIV transmission per sex act and the RR for increased transmissibility of primary HIV. Further details of the model and equations are provided in the supplementary material.

HIV was modelled with an initial short acute phase of high infectivity, followed by a long low-infectivity phase and a preAIDS phase of increased infectivity. ${ }^{13}$ It was assumed that those with AIDS are chronically ill, and cease being sexually active. HSV-2 coinfection ${ }^{14}$ and syphilis ${ }^{15}$ were also modelled dynamically, with cofactors representing facilitation of HIV and HSV-2 acquisition and transmission.

The setting-specific behaviour-related, demographic-related and intervention-related prior model parameter distributions were derived from detailed serial cross-sectional behavioural and biological data (from IBBAs) collected from FSWs and their clients, and general population surveys (GPS) carried out as part of the Avahan monitoring programme, as well as from complementary data from other sources. The non-setting specific biological parameter ranges were based on reviews of relevant literature (tables 2 and 3). Prior distributions were assumed to be uniform across each parameter range; this was a 'conservative' choice to reflect the lack of precise knowledge

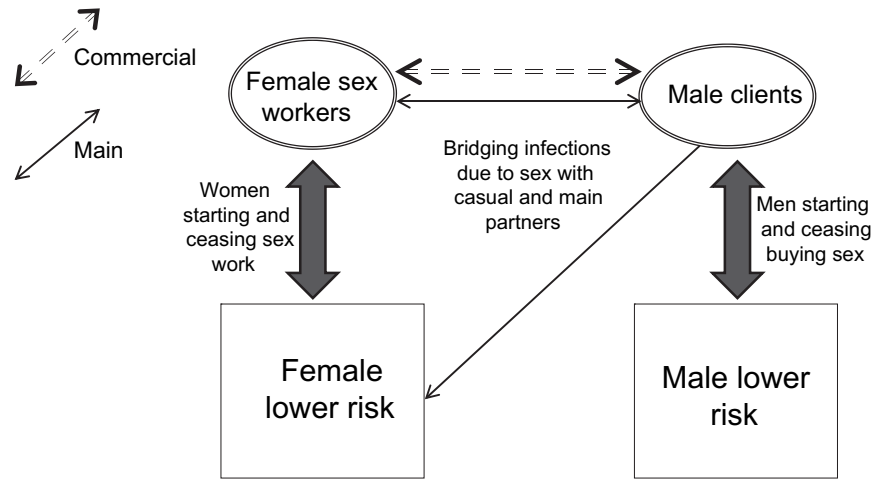

Figure 1 Outline of the main aspects of sexual behaviour structure and population movements between risk groups that are included in the model. HIV/sexually transmitted infection (STI) transmission through main (plain arrow) and casual (dotted arrow) partnerships is shown. Female sex workers and clients engage in commercial sex for a time before returning to the general population and being replaced from the general population (thick arrow). 
and possibility of bias in the data used to estimate the parameters.

The parameterisation of condom use before and after the intervention was data driven and specific to each hypothesis tested, resulting in three different prior condom use distributions. The prior distribution of condom use for hypothesis $\mathrm{H}_{1}$ was based on estimates (with CIs) of site-specific condom use from 2001 onwards given by the analysis of Lowndes et al. ${ }^{75}$ That analysis used data from the IBBA round 2 surveys concerning time since starting to use condoms consistently with occasional clients to retrospectively 'reconstruct' the fraction of FSWs consistently using condoms each year from 2001 to the year of the survey. The null hypothesis $\mathrm{H}_{0}$ assumed the same increase in condom use prior to 2004 as hypothesis $\mathrm{H}_{1}$ but no further increase after the start of the Avahan intervention in 2004. A further hypothesis $\left(\mathrm{H}_{2}\right)$ was based on HIV prevention programme data and other sources regarding the availability of condoms for FSWs ${ }^{9}$ from 2004 to 2008 across Karnataka. This study suggested that the proportion of consistent condom users among FSWs in 2004 was much lower than suggested in hypothesis $\mathrm{H}_{1}$ due to low availability, but that it rose steeply during 2006-2008 due to the Avahan intervention. The three different condom prior distributions are shown in figure 2, with the round 1 and 2 FSW IBBA point estimates shown for comparison.

\section{Parametric uncertainty analysis, model fitting and validation}

This step involved identifying combinations of model parameters that agreed with ('fit') the HIV/STI prevalence data from each site for each condom use hypothesis tested. Latin hypercube sampling (LHS) was used to sample several million parameter sets from all 'prior' parameter ranges for each hypothesis and district, with the sampling done so that the same set of parameters, excluding the intervention parameters being tested, were used for the different hypotheses in each district. The model was run with each sampled parameter set to predict HIV/STI prevalences. A parameter set was accepted as a fit if the model predictions simultaneously lay within the $95 \%$ CIs of the HIV, HSV-2 and syphilis prevalence data of the relevant FSW and client IBBAs, as described below.

The HIV/STI prevalence data from FSWs and clients for each district were used in two stages: (1) as validation and (2) for hypothesis testing. In stage 1 , the model was first fitted to just the round 1 FSW and client IBBA HIV, HSV-2 and syphilis prevalence data (see table 1), and the predictive value of these model fits was assessed against the HIV prevalence data not used directly at this stage of the fitting process, namely FSW HIV prevalence from the second round FSW IBBA in Mysore and Belgaum (table 1) and third round in Mysore (table 1), and FSW HIV prevalence by typology (street, brothel or home based) in rounds 1 and 2 (see supplementary material). In stage 2 , the second round of IBBA HIV prevalence data were included in the fitting procedure along with the first round of FSW and client IBBA HIV/STI prevalence data (table 1) to produce a reduced set of model fits for hypothesis testing.

\section{Testing hypotheses of condom use}

The most likely condom use hypothesis was determined based on the relative proportions of fits to the first round FSW and client IBBA HIV/STI prevalence data and the second round FSW HIV prevalence data. For each hypothesis, the fraction of model fits from all parameter sets was compared to determine which hypothesis was more likely. This method, which is related to the version of Approximate Bayesian Computing as described by
Weiss and von Haeseler, ${ }^{76}$ is also similar to the Bayesian methods used by Vickerman et al for determining the likelihood of different injecting drug user risk behaviour scenarios in Pakistan, ${ }^{77}$ and Hallett et al for examining behaviour change in Zimbabwe. $^{78}$

\section{Impact analysis}

The posterior distribution of the most likely condom use hypothesis was used to simulate HIV prevalence and incidence over time following the start of the intervention, and in a matched control population. In the latter, each model fit was run again with condom use kept constant at 2004 levels (ie, at the start of the Avahan initiative). Comparing the impact and control scenarios, estimates of the impact of the increase in condom use following the start of the intervention among highrisk groups were derived for a 5-year period (2004-2009). These estimates derived from the posterior distribution include credibility intervals (CrI) generated by using all the parameter combinations that fit the prevalence data to reflect the uncertainty in parameter assumptions, since more than one set of parameters may produce an equally good fit to epidemiological trends.

\section{RESULTS}

\section{Hypothesis testing}

The proportion of fits to each hypothesis is shown in table 4. In Mysore, the hypothesis $\mathrm{H}_{2}$, derived from analysing availability of condoms, gives the largest proportion of simulations which are consistent with prevalence data, and scenarios $\mathrm{H}_{2}$ and $\mathrm{H}_{1}$ of increasing condom use following the introduction of Avahan are more likely than the null hypothesis $\mathrm{H}_{0}$ of no condom increase after the start of Avahan, for which no model fits were obtained. In Belgaum, however, the null hypothesis $\mathrm{H}_{0}$ of no increase use in condom use following Avahan and the alternative hypothesis $\mathrm{H}_{1}$, based on the historical condom use reconstruction, cannot be distinguished by this method, although both are much more likely than the hypothesis $\mathrm{H}_{2}$. An alternative method to comparing the proportion of fits would be a likelihood-based approach, calculating the likelihood for each run; however this method gave comparable results (data not shown).

\section{Crossvalidation of results}

Table 4 shows that fits to only the round 1 FSW and client IBBA prevalence data (table 4) also generally fit the round 2 FSW IBBA HIV prevalence data well for all hypotheses $(90 \%$ or more of posterior runs also fit FSW HIV round 2 prevalence). This then validates the model with respect to time trends in HIV (see also supplementary material). A third round of IBBA data was available for Mysore only, and the model HIV prevalence projections were slightly higher $\left(12.1 \%\right.$ to $20.6 \%$ for $\mathrm{H}_{2} ; 12.4 \%$ to $19.6 \%$ for $\mathrm{H}_{1}$ ) than the third round IBBA data (8.1\% to $\left.14.1 \%\right)$. This is consistent with the fact that any further increases subsequent to the IBBA round 2 in condom use were not incorporated in the model.

Lastly, validation of the model by comparing its projections with FSW HIV prevalence by typology generally showed good agreement, although there was some residual heterogeneity, as might be expected (see supplementary material).

\section{Trends in HIV/STI prevalence and incidence}

The predicted prevalences over time for the model fits from the favoured hypotheses $\left(\mathrm{H}_{0}\right.$ and $\mathrm{H}_{1}$ for Belgaum and $\mathrm{H}_{2}$ for Mysore) suggest that the HIV epidemics among FSWs and clients are declining in both districts (figure $3 \mathrm{~A}-\mathrm{F}$ ). In Belgaum, it is likely 
Table 2 Prior biological model input parameters sampled at the fitting stage to obtain the posterior parameter sets for Mysore and Belgaum for the Avahan impact model (all durations are in months)

\begin{tabular}{|c|c|c|c|}
\hline Types of model input & Definition of model input & Model inputs & Reference for model input value \\
\hline \multirow{21}{*}{$\begin{array}{l}\text { Duration of } \\
\text { infection stages }\end{array}$} & Average duration of $\mathrm{Ng} / \mathrm{Ct}$ : & & \multirow{4}{*}{$\begin{array}{l}\text { Reviewed in Korenromp et al. }{ }^{16} \text { Also depends on level of STI } \\
\text { treatment. }\end{array}$} \\
\hline & Males & $2-5$ & \\
\hline & Females & $2-12$ & \\
\hline & Female sex workers (FSWs) & $0.5-3$ & \\
\hline & Average duration of syphilis stages: & & \multirow{7}{*}{$\begin{array}{l}\text { Available data was reviewed by Boily et al and } \\
\text { Garnett et } a l^{8} 15\end{array}$} \\
\hline & Primary (no treatment) & 1.51 & \\
\hline & Secondary (no treatment) & $3-4.5$ & \\
\hline & Primary and secondary stage (with treatment) & $1-5$ & \\
\hline & Latent phase (including treatment) & $2-24$ & \\
\hline & Time between potential recurrences & 6 & \\
\hline & Immune/resistant phase & $12-60$ & \\
\hline & Average duration of HSV-2 stages: & & \multirow{4}{*}{$\begin{array}{l}\text { From Cheong et al, Corey et al, Diamond et al, Koelle et al, } \\
\text { Guinan et al and Benedetti et al. }{ }^{17-24} \\
\text { Using Corey et al, Guinan et al and Wald et al. }{ }^{18202325-27}\end{array}$} \\
\hline & Primary stage & $0.36-0.66$ & \\
\hline & Symptomatic recurrence & $0.1-0.16$ & \\
\hline & Rate of HSV-2 symptomatic recurrences while: & & \\
\hline & HIV negative & $0.09-0.41$ & $\begin{array}{l}\text { Corey et al, Diamond et al, Benedetti et al, Lafferty et al and } \\
\text { Kim et al }{ }^{18} 20212428-30\end{array}$ \\
\hline & HIV positive & $1-2 \times$ HIV negative rate & Using Schacker et al and Conant et $a l^{3132}$ \\
\hline & Average duration of HIV stages: & & \multirow[t]{4}{*}{ Based on Grover and Shivraj, and Kumarasamy et al ${ }^{33} 34$} \\
\hline & Initial HIV high viraemia phase & $4-6$ & \\
\hline & Between initial high viraemia and pre-AIDS & $70-90.5$ & \\
\hline & Pre-AIDS high viraemia phase & $6-18$ & \\
\hline \multirow{14}{*}{$\begin{array}{l}\text { Transmission } \\
\text { probabilities }\end{array}$} & \multicolumn{2}{|l|}{ Probability of HIV transmission per sex act: } & \multirow[t]{6}{*}{ Reviewed in Holmes et al. ${ }^{4067}$} \\
\hline & Male to female: & $0.0006-0.0011$ & \\
\hline & Female to male & $0.0001-0.0014$ & \\
\hline & Sexual transmission multiplicative cofactor: & & \\
\hline & Initial high viraemia phase & $4.5-18.8$ & \\
\hline & Pre-AIDS high viraemia phase & $4.5-11.9$ & \\
\hline & Probability of $\mathrm{Ng} / \mathrm{Ct}$ transmission per sex act & $0.05-0.2$ & \multirow{4}{*}{$\begin{array}{l}\text { Reviewed by Holmes et al, Hooper et a }\left.\right|^{40} 67 \\
\text { Reviewed by Garnett et al }{ }^{15}\end{array}$} \\
\hline & $\begin{array}{l}\text { Probability of syphilis transmission per sex act (male to } \\
\text { female): }\end{array}$ & $0.1-0.3$ & \\
\hline & $\begin{array}{l}\text { Ratio of transmission probabilities female to male:male to } \\
\text { female }\end{array}$ & $0.33-1.0$ & \\
\hline & Probability of HSV-2 transmission: & & \\
\hline & Latent/asymptomatic shedding stage (male to female) & $0.0005-0.002$ & \multirow[t]{2}{*}{ Using Wald et al and Corey et a/ $/^{37} 38$} \\
\hline & RR male to female: female to male transmission & $2-5$ & \\
\hline & Primary stage & $\begin{array}{l}2-6 \times 6.7-25 \text { times } \\
\text { asymptomatic/latent transmission } \\
\text { probability }\end{array}$ & \multirow{2}{*}{$\begin{array}{l}\text { From Kim et al, Wald et al and Corey et al }{ }^{303738} \\
\text { Wald et al, Kim et al, and Mertz et } a l^{25} 3039-41\end{array}$} \\
\hline & Symptomatic recurrence stage & $\begin{array}{l}1-3 \times 6.7-25 \\
\text { times latent/asymptomatic } \\
\text { transmission probability }\end{array}$ & \\
\hline \multirow[t]{8}{*}{ Cofactors for HIV } & $\begin{array}{l}\text { Average } \mathrm{Ng} / \mathrm{Ct} \text { cofactor per sex act for increasing } \\
\text { susceptibility to HIV }\end{array}$ & $1.2-2.5$ & \multirow[t]{5}{*}{ Using Rottingen et $a l^{13}$} \\
\hline & $\begin{array}{l}\text { Average syphilis cofactor per sex act for increasing } \\
\text { susceptibility to HIV }\end{array}$ & $2.1-3.3$ & \\
\hline & HSV-2 cofactor per sex act for increasing HIV infectivity: & & \\
\hline & Primary and symptomatic recurrence phases & $1.27-2.57 \times 1-2$ & \\
\hline & Asymptomatic/latent phase & $0.27-1.57 \times 0.04-0.15 \times 2-3$ & \\
\hline & \multicolumn{2}{|c|}{ HSV-2 cofactor per sex act for increasing HIV susceptibility: } & \multirow{3}{*}{$\begin{array}{l}\text { Using Schacker et al, Nagot et al, Zuckerman et al, Baeten } \\
\text { et al, Celum et al, Dunne et al, Delany et al, Mbopi-Keou et } \\
\text { al, Augenbraun et al, LeGoff et al and Serwadda et }\left.a\right|^{3142-54} \\
\text { and Quinn et al }{ }^{55} \text { to convert from differences in HIV viral } \\
\text { load }\end{array}$} \\
\hline & Asymptomatic/latent phase & $1-4.75$ & \\
\hline & Primary phase and symptomatic recurrence phase & $\begin{array}{l}1.5-4.0 \text { times asymptomatic } \\
\text { cofactor }\end{array}$ & \\
\hline \multirow[t]{4}{*}{ Cofactors for HSV-2 } & HIV cofactor per partnership for increasing HSV-2 infectivit & & \multirow{4}{*}{$\begin{array}{l}\text { Using Celum et al, Corey et al, Freeman et al and Watson- } \\
\text { Jones et } a l^{45} 56-58 \text { and converting to probability using } \\
\text { Quinn et } a l^{55}\end{array}$} \\
\hline & Primary phase & $1-2.5$ & \\
\hline & Asymptomatic/latent phase & $2-4$ & \\
\hline & Symptomatic recurrence phase & Same as primary & \\
\hline \multirow[t]{3}{*}{ Condom efficacies } & Condom efficacy per sex act for HIV & $80 \%$ to $95 \%$ & Pinkerton et $a f^{5960}$ \\
\hline & Condom efficacy per sex act for HSV-2 and syphilis & $40 \%$ to $70 \%$ & $\begin{array}{l}\text { Based on Wald et al, Oberle et al, Dobbins et al, Obasi et al } \\
\text { and Huerta et al }{ }^{37} 61_{-65}\end{array}$ \\
\hline & Condom efficacy per sex act for $\mathrm{Ng} / \mathrm{Ct}$ & $60 \%$ to $90 \%$ & $\begin{array}{l}\text { Based on Holmes et al, Hooper et al, Austin et al, Barlow, } \\
\text { Joesof et al, Sanchez et al, Gaydos et al, Niccolai et al and } \\
\text { Zenilman et al }{ }^{66-74}\end{array}$ \\
\hline
\end{tabular}


Table 3 Prior behavioural model input parameters sampled at the fitting stage to obtain the posterior parameter sets for Mysore and Belgaum for the Avahan impact model

\begin{tabular}{|c|c|c|c|}
\hline Types of model input & Definition of model input & Mysore & Belgaum \\
\hline \multicolumn{4}{|l|}{ Demography } \\
\hline \multirow[t]{8}{*}{ Population size and demographic inputs } & \multirow[t]{2}{*}{ Initial size of sexually active population } & 278000 (M) & 268000 (M) \\
\hline & & $268000(\mathrm{~F})$ & $257000(\mathrm{~F})$ \\
\hline & $\begin{array}{l}\text { Fraction of female general population } \\
\text { sexually active }\end{array}$ & $75 \%$ to $95 \%$ & $77 \%$ to $95 \%$ \\
\hline & $\begin{array}{l}\text { Fraction of male general population } \\
\text { sexually active }\end{array}$ & Determined by available partnerships & Determined by available partnerships \\
\hline & \multirow[t]{2}{*}{ Average time spent sexually active } & 41.3 years (M) & 41.5 years (M) \\
\hline & & 42.4 years $(F)$ & 42.2 years $(F)$ \\
\hline & \multirow{2}{*}{$\begin{array}{l}\text { Entry rate into sexually active population } \\
\text { per year }\end{array}$} & 12000 (M) & 12000 (M) \\
\hline & & $11000(\mathrm{~F})$ & $11000(\mathrm{~F})$ \\
\hline \multirow[t]{2}{*}{ Migration of female sex workers (FSWs) } & Proportion of FSWs migrating & $0.3-0.44$ & $0.05-0.20$ \\
\hline & $\begin{array}{l}\text { Multiplicative cofactor increasing } \\
\text { prevalence of HIV among clients in sites to } \\
\text { which FSWs migrate }\end{array}$ & $1-2$ & $1-2$ \\
\hline \multicolumn{4}{|l|}{ Sexual behaviour } \\
\hline \multirow{16}{*}{$\begin{array}{l}\text { Long-term partnerships of FSWs and } \\
\text { clients }\end{array}$} & \multicolumn{3}{|c|}{ Percentage of clients currently married/cohabiting by duration: } \\
\hline & $0-1$ years and $2-4$ years & $68 \%$ & $43 \%$ to $59 \%$ \\
\hline & $5-9$ years and $10+$ years & $68 \%$ & $83 \%$ to $93 \%$ \\
\hline & \multicolumn{3}{|c|}{ Percentage of FSWs currently married/cohabiting by duration: } \\
\hline & $0-1$ years & $38.2 \%$ to $57.2 \%$ & $9.8 \%$ to $40.3 \%$ \\
\hline & $2-4$ years & $39.9 \%$ to $54.9 \%$ & $11.6 \%$ to $39.9 \%$ \\
\hline & $5-9$ years & $28.6 \%$ to $50.4 \%$ & $21.5 \%$ to $48.6 \%$ \\
\hline & $10+$ years & $23.1 \%$ to $46 / 7 \%$ & $5.3 \%$ to $20.7 \%$ \\
\hline & \multicolumn{3}{|c|}{ Percentage of FSWs currently married/cohabiting by typology: } \\
\hline & Home based & $25.9 \%$ to $54.1 \%$ & $11.4 \%$ to $29.7 \%$ \\
\hline & Brothel based & $8.8 \%$ to $66.9 \%$ & $13.1 \%$ to $28.9 \%$ \\
\hline & Street based & $39.3 \%$ to $49.3 \%$ & $9.0 \%$ to $43.9 \%$ \\
\hline & Average frequency of sex acts with & $5.9-8.2$ (clients) & 9.5-11.7 (clients) \\
\hline & $\begin{array}{l}\text { married/cohabiting partner for FSWs/ } \\
\text { clients (per month) }\end{array}$ & $5.9-8.2(\mathrm{FSWs})$ & $5.6-9.5(\mathrm{FSWs})$ \\
\hline & $\begin{array}{l}\text { Duration of long-term partnerships } \\
\text { (cohabiting/married) if FSW, years }\end{array}$ & $8.6-13.0$ & $16.6-21.7$ \\
\hline & $\begin{array}{l}\text { Duration of long-term partnerships } \\
\text { between clients and low-risk females, } \\
\text { years }\end{array}$ & $20-30$ & $20-30$ \\
\hline \multirow[t]{18}{*}{ FSW sexual behaviour } & \multicolumn{3}{|l|}{ Average weekly frequency of clients for: } \\
\hline & Home-based FSWs duration $0-1$ years & $2.5-5.1$ & $5.5-26.1$ \\
\hline & Home-based FSWs duration 2-4 years & $3.8-7.9$ & $1.8-10.3$ \\
\hline & Home-based FSWs duration $5-9$ years & $2.8-8.2$ & $5.7-10.0$ \\
\hline & Home-based FSWs duration $10+$ years & $4.6-14.6$ & $7.0-11.0$ \\
\hline & Brothel-based FSWs duration $0-1$ years & $15-25$ & $6.3-34.2$ \\
\hline & Brothel-based FSWs duration 2-4 years & $12-45$ & $13.5-26.2$ \\
\hline & Brothel-based FSWs duration $5-9$ years & $4-15$ & $13.1-25.3$ \\
\hline & Brothel-based FSWs duration $10+$ years & $5.2-16.6$ & $8.9-17.9$ \\
\hline & Street-based FSWs duration $0-1$ years & $6.5-9.2$ & $4.8-13.6$ \\
\hline & Street-based FSWs duration $2-4$ years & $7.5-9.4$ & $1.1-13.0$ \\
\hline & Street-based FSWs duration $5-9$ years & $7.2-9.8$ & $2.4-10.2$ \\
\hline & Street-based FSWs duration $10+$ years & $6.5-9.1$ & $3.8-10.2$ \\
\hline & Number of sex acts with each client & $1-3$ & $1-3$ \\
\hline & \multicolumn{3}{|c|}{ Average duration of sex work in months for: } \\
\hline & Home-based FSWs & $35-69$ & $160-224$ \\
\hline & Brothel-based FSWs & $49-189$ & $94-127$ \\
\hline & Street-based FSWs & $53-66$ & $138-251$ \\
\hline \multirow[t]{4}{*}{ Client sexual behaviour } & \multicolumn{3}{|l|}{ Number of FSWs visited/month if: } \\
\hline & Below median activity level & $0.8-1.2$ & $0.8-1.2$ \\
\hline & Above median activity level & $2.9-3.8$ & $2.32-2.78$ \\
\hline & $\begin{array}{l}\text { Average duration of being client in months } \\
\text { if below/above median activity level }\end{array}$ & $84-240 / 84-240$ & $83-119 / 90-143$ \\
\hline
\end{tabular}


Table 3 Continued

\begin{tabular}{|c|c|c|c|}
\hline Types of model input & Definition of model input & Mysore & Belgaum \\
\hline \multirow[t]{9}{*}{$\begin{array}{l}\text { Proportions of FSWs/clients by each } \\
\text { stratification }\end{array}$} & $\begin{array}{l}\text { Percentage of female population who are } \\
\text { FSWs }\end{array}$ & $0.3 \%$ to $1.4 \%$ & $0.2 \%$ to $1.1 \%$ \\
\hline & $\begin{array}{l}\text { Percentage of male population who are } \\
\text { clients }\end{array}$ & $\begin{array}{l}\text { Determined by number of FSW } \\
\text { partnerships }\end{array}$ & $\begin{array}{l}\text { Determined by number of FSW } \\
\text { partnerships }\end{array}$ \\
\hline & \multicolumn{3}{|l|}{ Proportion of FSWs that are: } \\
\hline & Home based & $0.08-0.15$ & $0.23-0.50$ \\
\hline & Brothel based & $0.00-0.01$ & $0.31-0.61$ \\
\hline & Street based & $0.85-0.91$ & $0.11-0.24$ \\
\hline & \multicolumn{3}{|l|}{ Proportion of male clients who visit FSWs: } \\
\hline & $\begin{array}{l}\text { Below median level (ie, low activity } \\
\text { clients) }\end{array}$ & 0.5 & $0.58-0.69$ \\
\hline & $\begin{array}{l}\text { Above median level (ie, high activity } \\
\text { clients) }\end{array}$ & 0.5 & $0.31-0.42$ \\
\hline \multicolumn{4}{|l|}{ Condom use } \\
\hline Condom use in main partnerships & $\begin{array}{l}\text { Average consistency of condom use } \\
\text { between married/cohabiting partners per } \\
\text { sex act. }\end{array}$ & $4.3 \%$ to $10.3 \%$ & $5.2 \%$ to $12.7 \%$ \\
\hline \multirow[t]{13}{*}{ Condom use between FSWs and clients } & \multicolumn{3}{|c|}{ Fraction of sex acts with occasional clients for which a condom is used, by FSWs who: } \\
\hline & Report 'always' using & $0.81-0.93$ & $0.81-0.93$ \\
\hline & Report often/sometimes using & $0.54-0.67$ & $0.54-0.67$ \\
\hline & Report 'never' using & $0.07-0.38$ & $0.07-0.38$ \\
\hline & \multicolumn{3}{|c|}{ Fraction of FSWs who are consistent condom users: } \\
\hline & $\begin{array}{l}\text { At the start of the HIV epidemic in India } \\
\text { Under } \mathrm{H}_{0} \text { and } \mathrm{H}_{1} \text { : }\end{array}$ & $0-0.1$ & $0-0.1$ \\
\hline & At first time point & $0.111-0.228$ & $0.286-0.422$ \\
\hline & At second time point & $0.233-0.395$ & $0.759-0.855$ \\
\hline & \multicolumn{2}{|l|}{ Under $\mathrm{H}_{2}$ : } & $0.855-0.926$ \\
\hline & At first time point & $0.1-0.220$ & $0.1-0.220$ \\
\hline & At second time point & $0.321-0.416$ & $0.321-0.416$ \\
\hline & At time of IBBA R2 & $0.777-0.847$ & $0.777-0.847$ \\
\hline & $\begin{array}{l}\text { Fraction of FSWs who report 'sometimes/ } \\
\text { often' using condoms with occasional } \\
\text { clients at IBBA R2 }\end{array}$ & $0.245-0.367$ & $0.074-0.145$ \\
\hline \multirow[t]{9}{*}{ Dates } & Start of HIV epidemic in India & $1976-1985$ & $1976-1985$ \\
\hline & \multicolumn{3}{|l|}{ Under $\mathrm{H}_{0}$ and $\mathrm{H}_{1}$ : } \\
\hline & At first time point & 2002 & 2002 \\
\hline & At second time point & 2004 & 2005 \\
\hline & At time of IBBA R2 & 2007 & 2008 \\
\hline & \multicolumn{3}{|l|}{ Under $\mathrm{H}_{2}$ : } \\
\hline & At first time point & 2004 & 2004 \\
\hline & At second time point & 2006 & 2006 \\
\hline & At time of IBBA R2 & 2008 & 2008 \\
\hline
\end{tabular}

FSW, female sex worker; $H$, hypothesis; IBBA, integrated behavioural and biological assessments; $R$, round.

that this decline began before Avahan started, around the year 2000, while in Mysore the decline probably started shortly after Avahan, in 2004-2005. Modelled incidence and the prevalence for hypothesis $\mathrm{H}_{1}$ for Mysore show similar trends (see supplementary material). More details of the general characteristics of the model runs and fits are included in the supplementary material.

In Mysore, the median relative decline in HIV prevalence in 2009 compared to 2004 ('time decline') under $\mathrm{H}_{2}$ was $36.2 \%$ (95\% CI $21 \%$ to $51 \%$ ) in FSWs (median $25.6 \%$, 95\% CI $7 \%$ to $42 \%$ in clients), whereas the median relative decline in 2009 prevalence compared to a simulated scenario without any increase in condom use since 2004 ('intervention decline') was $44.7 \%$ (95\% CI $35 \%$ to $52 \%$ ) in FSWs (37.9\%, $95 \%$ CI $30 \%$ to $45 \%$ in clients). In Belgaum, under $\mathrm{H}_{1}$, the median time decline was $47.6 \%$ (95\% CI 39\% to 58\%) in FSWs (median $55.7 \%$, 95\% CI $48 \%$ to $66 \%$ in clients) while the median intervention decline was actually lower at $23.1 \%$ (95\% CI $17 \%$ to $30 \%$ ) in FSWs (28.4\%, $95 \%$ CI $22 \%$ to $36 \%$ in clients). Thus, the time decline in
HIV prevalence slightly underestimates the intervention decline in Mysore for hypothesis $\mathrm{H}_{2}$ and overestimates it in Belgaum for hypothesis $\mathrm{H}_{1}$.

\section{Intervention impact among high-risk groups}

We estimated the impact of the increase in condom use following the start of Avahan using the most likely hypothesis as the simulated intervention group/population, and using the null hypothesis $\mathrm{H}_{0}$ as the simulated matched control group/ population. In Mysore, the increase in condom use between 2004 and 2009 may have prevented $31.3 \%$ to $47.4 \%$ of new HIV infections in FSWs and $32.7 \%$ to $47.2 \%$ in clients under hypothesis $\mathrm{H}_{2}$ (figure 4 shows this in comparison to the impact projections for hypothesis $\mathrm{H}_{1}$ ). Impact increases over time, with $58.7 \%$ to $82.2 \%$ of new HIV infections prevented among FSWs in 2008 and $64.1 \%$ to $85.1 \%$ among clients under hypothesis $\mathrm{H}_{2}$ ( $41.2 \%$ to $72.2 \%$ and $47.1 \%$ to $77.6 \%$ under $\mathrm{H}_{1}$ ).

In Belgaum, hypothesis $\mathrm{H}_{0}$, where condom use remains constant from 2004 onwards, suggests no impact. In 

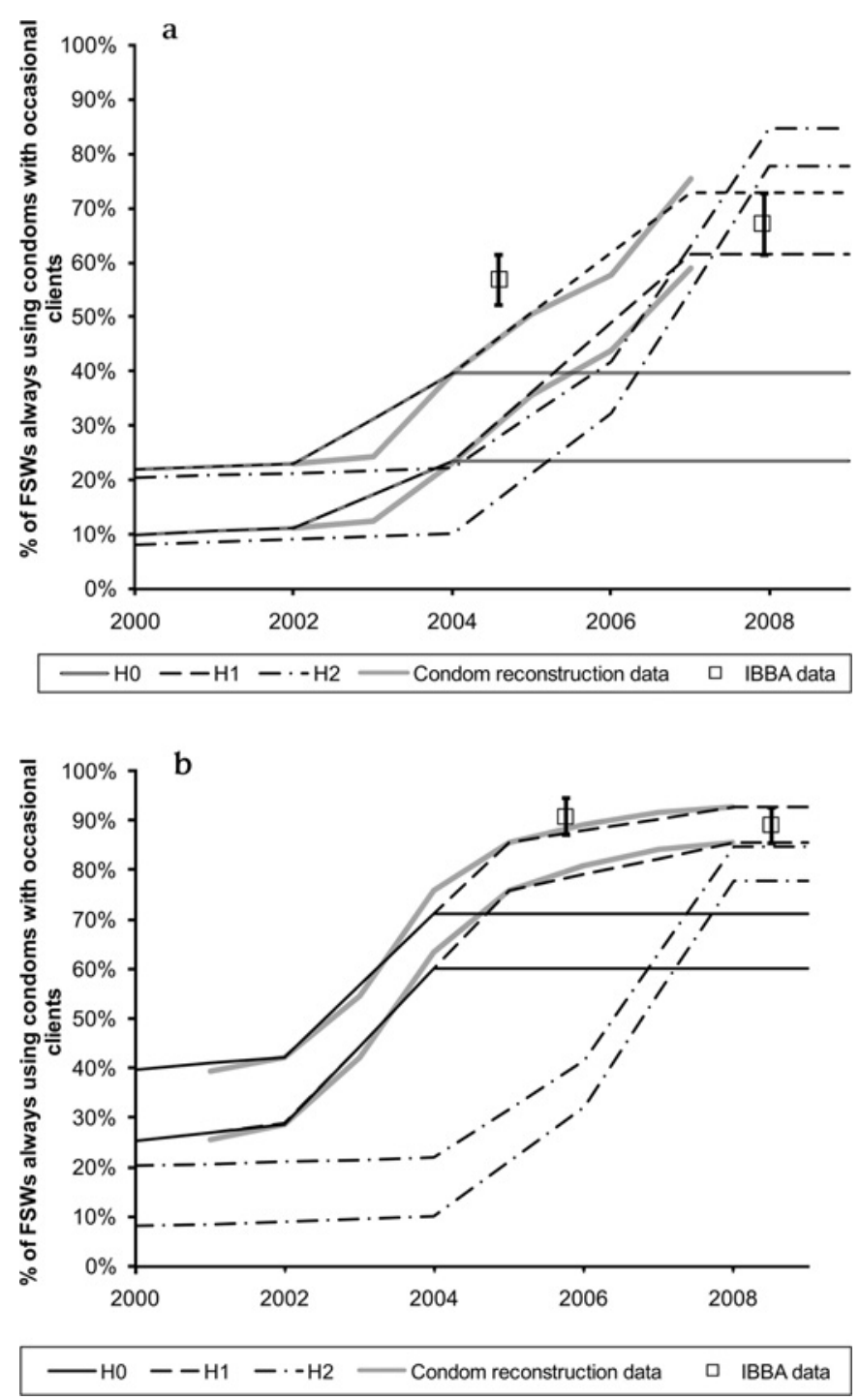

Figure 2 Prior parameter ranges for hypotheses $\mathrm{H}_{0}-\mathrm{H}_{2}$ reflecting the proportion of female sex workers (FSWs) who are consistently using condoms for (a) Mysore and (b) Belgaum. The upper and lower lines show the range of the prior. Also shown is the data from the historic condom reconstruction, and mean and $95 \%$ Cls for the FSW integrated behavioural and biological assessment (IBBA) values.

comparison, the $\mathrm{H}_{1}$ scenario projects that $24.8 \%$ to $43.2 \%$ of new FSW HIV infections and $30.9 \%$ to $53.1 \%$ of new client infections were prevented in Belgaum by the increase in condom use between 2004 and 2009 (figure 4). As for Mysore, impact increases over time in the $\mathrm{H}_{1}$ scenario, with $32.7 \%$ to $59.7 \%$ of new infections in FSWs and $42.0 \%$ to $72.6 \%$ in clients prevented in 2008 .

\section{DISCUSSION}

With sufficient data to inform model parameters and validate model predictions, the use of mathematical models within a Bayesian framework enables the testing of hypotheses about the value or range of more uncertain parameters, ${ }^{77} 78$ such as the evolution of condom use over time. In this analysis we have tested whether condom use is likely to have increased following the implementation of the Avahan intervention. In theory this could have been done more directly if unbiased baseline data on condom use had been collected; however, in practice it was not possible because such data could only be collected once the intervention was sufficiently well established to map and sample FSWs.

The success rates obtained in the hypothesis-testing analysis support the conclusion that in Mysore condom use during commercial sex increased substantially after the beginning of the intervention. This increase most likely occurred shortly after the beginning of the intervention, as suggested by data on availability of condoms. Although there was no significant decrease in the FSW IBBA prevalence data between rounds 1 and 2, the model suggests that, in the absence of an increase in condom use after 2004, prevalence would have increased, and so to obtain the required trend a significant increase in condom use was required. In Belgaum, the model results show that decreases in prevalence alone from the IBBA surveys are insufficient to distinguish between the hypotheses of increased condom use as reported by FSWs and constant condom use following the beginning of the intervention. Without information from other sources, it is not possible to definitely conclude that there has been an increase in condom use in commercial sex in Belgaum. The results also suggest that the level of condom use was higher in Belgaum than in Mysore prior to 2004. In Belgaum, a smaller-scale intervention was present for some years prior to $2004,{ }^{79}$ before it was scaled up by Avahan. Condom use by FSWs with clients may therefore have been higher at the start of the intervention than in Mysore, where there was no prior intervention.

The model results indicate that HIV incidence and prevalence have declined over time. The decline occurred earlier in Belgaum than in Mysore because condom use became widespread earlier, but perhaps also because the epidemic matured earlier. In Mysore, the decline roughly coincides with the beginning of the intervention. This pattern of decrease in prevalence agrees with that seen by Vickerman et $a l^{4}{ }^{4}$ and by Boily et al ${ }^{80}$ examining ANC data. While this study only considers high-risk individuals, the decline observed among FSWs and clients should translate to a slower decline in the general population in both districts, as shown in the analysis by Vickerman et al. ${ }^{4}$

The relative decline in HIV prevalence in Mysore in 2009 compared to the simulated control group ('intervention decline') is higher than the decline over time since 2004 ('time decline'). This is because the epidemic was still growing in 2004. In Belgaum, under the hypothesis of increasing condom use after

Table 4 Number of fits per million runs for each hypothesis $(\mathrm{H})$ (fits to round $(\mathrm{R}) 1$ data only are shown for comparison to validate time trends of the model in HIV prevalence)

\begin{tabular}{|c|c|c|c|c|c|c|}
\hline & \multicolumn{3}{|l|}{ Mysore } & \multicolumn{3}{|l|}{ Belgaum } \\
\hline & $\begin{array}{l}\mathrm{H}_{0}: \text { condom use } \\
\text { fixed since } 2004\end{array}$ & $\begin{array}{l}\mathrm{H}_{1} \text { : condom use as } \\
\text { reconstructed from } \\
\text { IBBA round } 2 \text { data }\end{array}$ & $\begin{array}{l}\mathrm{H}_{2}: \text { condom use follows } \\
\text { condom availability trends } 9\end{array}$ & $\begin{array}{l}\mathrm{H}_{0} \text { : condom use } \\
\text { fixed since } 2004\end{array}$ & $\begin{array}{l}\mathrm{H}_{1} \text { : condom use as } \\
\text { reconstructed from } \\
\text { IBBA round } 2 \text { data }\end{array}$ & $\begin{array}{l}\mathrm{H}_{2} \text { : condom use follows } \\
\text { condom availability } \\
\text { trends }\end{array}$ \\
\hline $\begin{array}{l}\text { Fits to } \mathrm{R} 1+\mathrm{R} 2 \mathrm{FSW} \\
\text { and client IBBAs }\end{array}$ & 0 & 36 (S) & 82.7 (S) & 9.7 & 8.3 (NS) & $0(S)$ \\
\hline
\end{tabular}

FSW, female sex worker; IBBA, integrated behavioural and biological assessments; NS, not statistically different to $\mathrm{H}_{0}$ at the $5 \%$ level using $\chi^{2}$ test; $\mathrm{S}$, statistically significantly different to $\mathrm{H}_{0}$. 


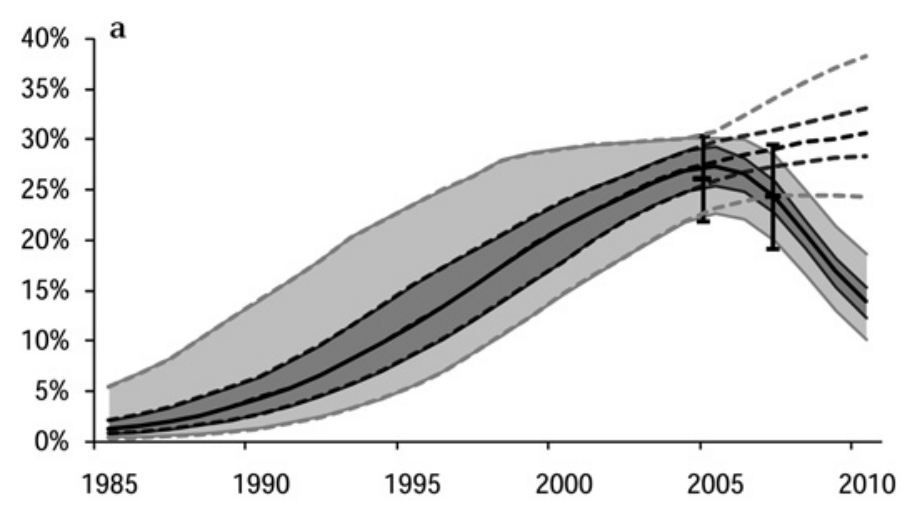

\begin{tabular}{ll|}
\hline Median model projection & --- Median (no intervention) \\
$-25 / 75$ percentiles & $---25 / 75$ percentiles (no intervention) \\
$-2.5 / 97.5$ percentiles & $---2.5 / 97.5$ percentiles (no intervention)
\end{tabular}
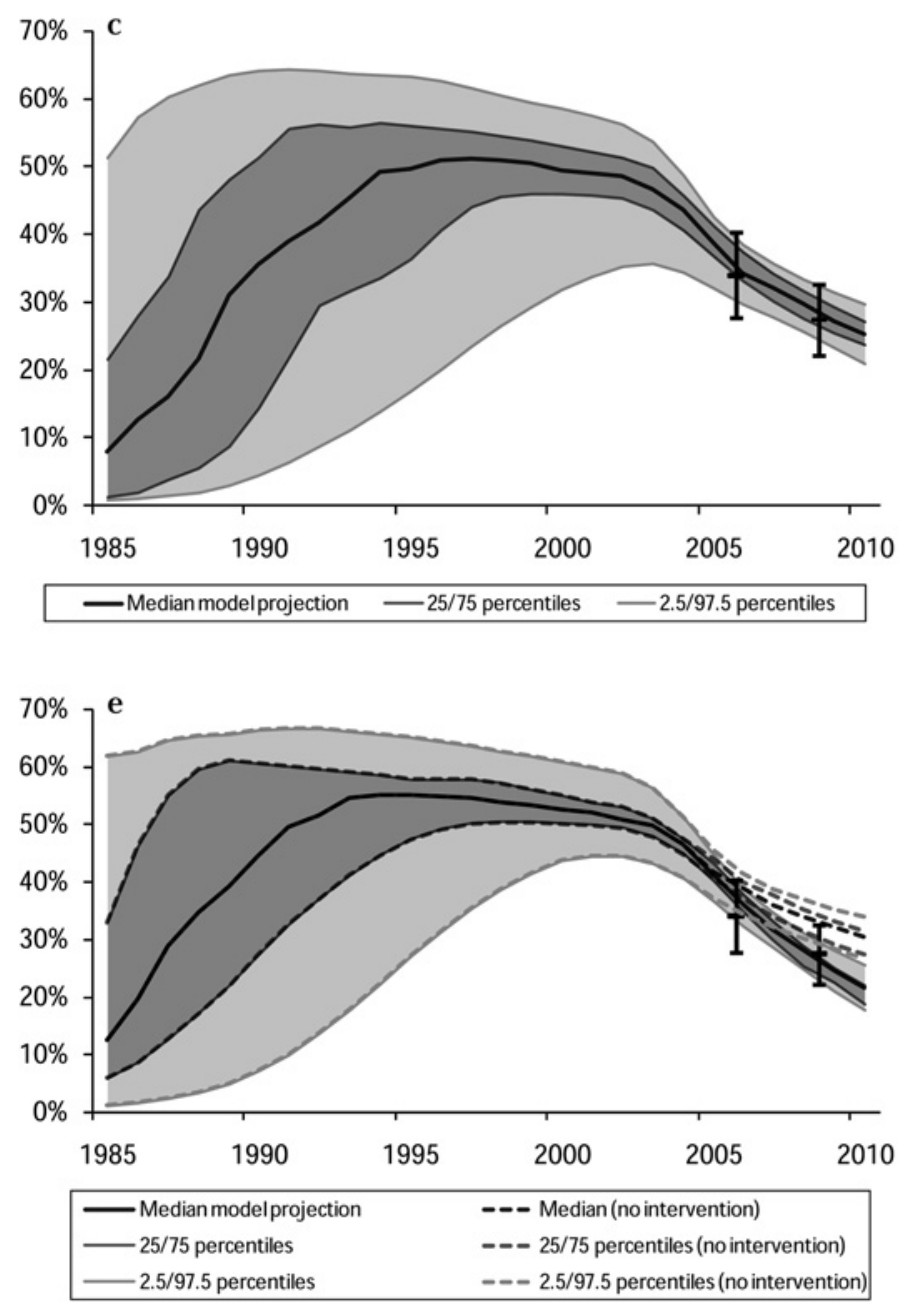
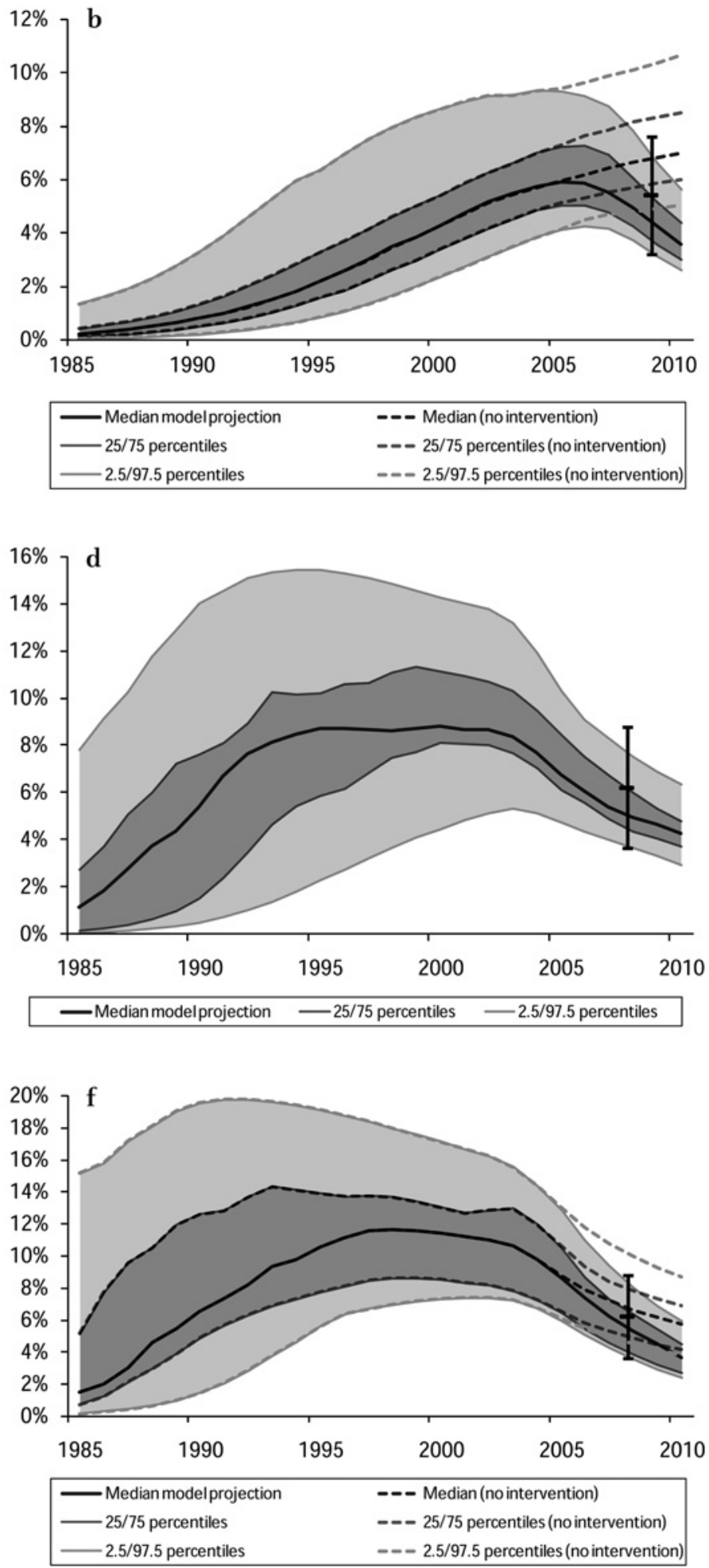

Figure 3 HIV prevalence over time for most likely hypothesis for (a) female sex workers (FSWs) and (b) clients in Mysore ( $\left.\mathrm{H}_{2}\right)$; (c) FSWs and (d) clients in Belgaum $\left(\mathrm{H}_{0}\right)$; and (e) FSWs and (f) clients in Belgaum $\left(\mathrm{H}_{1}\right)$. Shown on the graphs are median, 25th and 75th percentiles, and the 95\% credibility interval (lighter shaded area). For $\mathrm{H}_{1}$ Belgaum and $\mathrm{H}_{2}$ Mysore the prevalence of the simulated control groups is also shown (median, 25th and 75th percentiles, and $95 \%$ credibility interval). Also shown is the integrated behavioural and biological assessment (IBBA) prevalence data.

Avahan, the intervention decline is smaller than the time decline, as the epidemic there was already declining prior to Avahan. This highlights that time trends alone should not be used to evaluate an intervention, and that modelling results are important to complement prevalence data in carrying out an evaluation. 680

\section{Strengths and limitations}

The model described in this paper was specifically tailored to reflect the behavioural and biological heterogeneities present in these settings, with dynamical modelling of HSV-2 and syphilis in addition to HIV in each site. It was parameterised using data from multiple surveys among FSWs, clients and general 


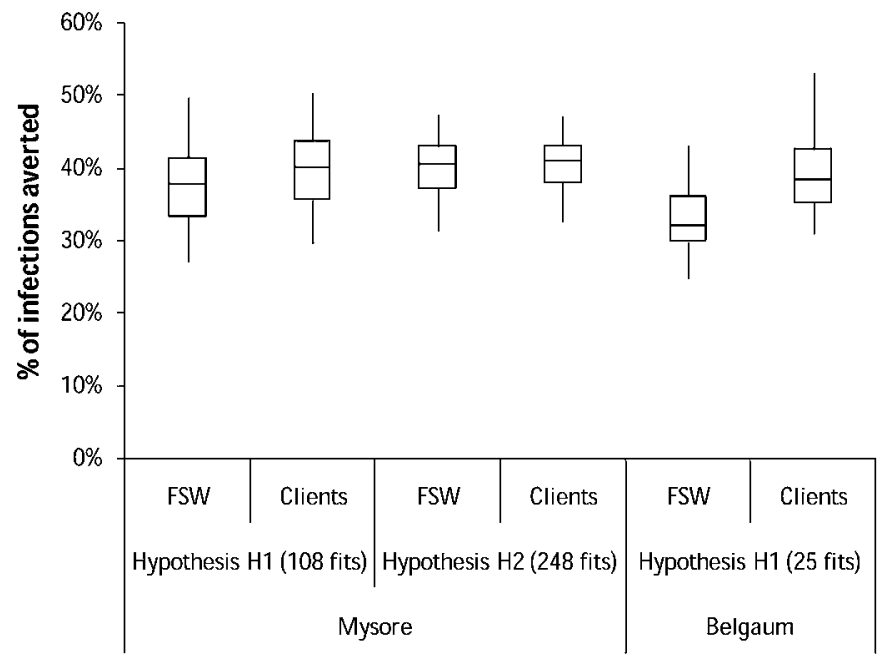

Figure 4 Fraction of new HIV infections averted over a 5-year period from 2004 in female sex workers (FSWs) and clients as a result of increases in condom use for (A) Mysore under hypotheses $\mathrm{H}_{1}$ and $\mathrm{H}_{2}$ and (B) Belgaum under hypotheses $\mathrm{H}_{1}$. Shown on the graph are the median (middle line in the box), 25th and 75th percentiles (box) and the 95\% credibility interval (whiskers). Belgaum hypothesis $\mathrm{H}_{0}$ corresponds to no impact, and is not shown.

population, and captured key epidemiological trends in HIV, HSV-2 and syphilis by risk groups. This model also compared well to an independent model by Vickerman $e t a l^{4}{ }^{4}$ and it was also validated with respect to time trends in HIV and FSW HIV prevalences by typology.

The framework described in Boily et $a l^{8}$ was used to produce point estimates and credibility intervals of intervention impact by the creation of control groups that assumed no increase in condom use. This control group gives the impact due to the increase in condom use since the beginning of the intervention, and, in situations where condom use would have increased naturally even without an intervention to drive it, will overestimate intervention impact. Conversely, in the absence of a likely increase in condom use following Avahan, as may have been the case in Belgaum, this choice of control group results in the model projecting no HIV infections averted, while it is possible that there would still have been a decline in condom use in this situation without an intervention to sustain it. Indeed, analysis of a slow, modest decrease in consistent condom use of $10 \%$ over 5 years suggests that even such a small decline in condom use leads to a large impact $(17.3 \%$ to $29.7 \%$ additional new FSW HIV infections between 2004-2009 due to the decrease in condom use), and thus the contribution of the intervention in sustaining condom use is important, although it is difficult to attribute directly.

The precision of the estimates was limited by data availability. In both districts, the fitting success rate was modest because conservative (wide) prior ranges were used for most parameters to capture their uncertainty, and because the model had to fit seven separate prevalence outcomes. If more data were available, then it would be possible to use this additional information to reduce the width of these priors and so possibly identify a higher proportion of model fits. This would allow a stronger comparison between the condom use scenarios, and would better reflect uncertainty in the impact projections. HIV prevalence data for earlier in the epidemic would also enable us to better constrain the trajectory of the early epidemic and so rule out unlikely epidemics with high early prevalence. However, using a constraint such as FSW prevalence being $<10 \%$ in 1985 did not change the impact estimates significantly (data not shown).

The picture is further complicated in Belgaum because the first IBBA survey was carried out 16 months after the start of the Avahan initiative, and so behavioural and epidemiological data reflected a situation in which Avahan was already present and where consistent condom use rates reported by FSW in the 2005 IBBA were already very high, at $91 \%$. In contrast, the survey in Mysore is likely to be more comparable to the preAvahan baseline as it took place 8 months after the start of Avahan. It is difficult to quantify the impact of a change in behaviour in situations where there was a pre-existing intervention and a long delay between the start of the intervention and the first IBBA survey, such as in Belgaum. Impact estimation is more uncertain in such settings because it is hard to define and simulate a control group reflecting how condom use would have decreased without the intervention, for which no data are available. An additional round of behavioural and HIV prevalence data for FSWs in Belgaum could help to further inform impact estimates by giving extra information about how the epidemic there is changing.

In Belgaum, the low number of fits from the model to the prevalence data may be largely explained by the difficulty of fitting the relatively high HIV prevalence in clients. This analysis modelled the transmission of HIV/STIs among urban clients, since the IBBA was carried out in urban areas where the intervention started. However the size of the FSW population is higher in rural areas, and as city clients may also go to smaller towns and villages to visit FSWs, the urban client HIV prevalence may be influenced by the large rural FSW population. Future data collection strategies for programme evaluation should be adapted to reflect the reality of how the epidemic is driven and the nature of the intervention.

\section{Conclusions}

Dynamical modelling, used within a Bayesian framework, is useful for testing hypotheses and providing informative and less subjective impact estimates on which to base decisions. This method of comparing proportions of fits of different scenarios is relatively straightforward to implement, as shown here and in another recent analysis, ${ }^{77}$ and helps to further augment survey findings of behaviours that are prone to reporting biases, such as condom use.

This analysis suggests that the HIV epidemics in Belgaum and Mysore are declining. In Belgaum, it is probable that the decline in HIV prevalence started before the beginning of the Avahan intervention, since condom use by FSWs with their clients was already high in this district due to pre-existing interventions. The model, using current prevalence data alone, is unable to distinguish between scenarios where condom use in commercial sex was sustained at existing levels and where it increased after Avahan. If there was a rise in condom use, as suggested by other data $^{9}$ and equally likely compared to the null hypothesis from this method, this increase would have averted $24.8 \%$ to $43.2 \%$ of HIV infections in FSWs and $30.9 \%$ to $53.1 \%$ of infections in clients between 2004 and 2009. If, however, Avahan only sustained the existing level of condom use attained by FSWs prior to Avahan, this is still important for controlling the epidemic, as even a small, gradual decline in condom use can greatly increase the number of new infections. This conclusion on impact, of including both scenarios, is conservative (which is deemed preferable), since the difference in proportion of fits between the hypotheses where condom use does or does not increase after 2004 is small. However, combined with the additional data 


\section{Key messages}

- Transmission dynamics models used within a Bayesian framework are useful tools to help evaluate large-scale intervention in absence of a control group. Such a framework enables testing of different hypotheses and provides credibility intervals for estimates of infections averted.

- Our modelling analysis suggests there has been a decrease in HIV prevalence in high-risk groups due to an increase in condom use since the beginning of the Avahan intervention in Mysore.

- Due to data limitations, our analysis could not say conclusively whether the change in prevalence in Belgaum was due to an increase in condom use following the start of the intervention, or simply the result of the natural dynamics and increase in condom use before 2004 .

presented in Bradley et a ${ }^{9}$ regarding the availability of condoms in Belgaum, it can be argued that it is likely that there has been an increase in condom use since the start of Avahan.

In Mysore, the findings strongly suggest that condom use during commercial sex has increased since the introduction of the Avahan programme, and that this increase in condom use has averted $31.3 \%$ to $47.4 \%$ of HIV infections in FSWs and $32.7 \%$ to $47.2 \%$ in clients in Mysore over the first 5 years.

Acknowledgements This research was funded by the Bill \& Melinda Gates Foundation. The views expressed herein are those of the authors and do not necessarily reflect the official policy or position of the Bill \& Melinda Gates Foundation, the London School of Hygiene \& Tropical Medicine, or Imperial College London. Many thanks to Jan Bradley of the CHARME-India project, Bangalore for useful discussions and to the London School of Hygiene and Tropical Medicine for use of the HPC.

Funding The Bill and Melinda Gates Foundation, Seattle, Washington, USA.

Competing interests None declared.

Contributors MP participated in the planning of the analysis, developed the mathematical model, performed the simulations and uncertainty analysis, interpreted results and wrote the manuscript; AMF participated in the planning of the analysis, helped in developing the mathematical model and in writing the manuscript; PV and MCB designed the analysis and helped in developing the mathematical model and in interpreting results and writing the manuscript; KD and SV performed analysis of the epidemiological and behavioural data, and carried out explanatory analyses which contributed in designing the model; ED preformed analyses of epidemiological and biological data; RW, BMR, SM, JB, CML, MA and SRP all provided published and unpublished epidemiological and behavioural data, and helped with interpretation of the data and revising the manuscript.

Provenance and peer review Not commissioned; externally peer reviewed.

\section{REFERENCES}

1. National AIDS Control Organisation, National Institute of Medical Statistics Ministry of Health and Family Welfare, Government of India. Technical report: India HIV estimates 2006. http://nacoonline.org/upload/NACO PDF/Technical Report on HIV Estimation 2006.pdf (accessed 22 May 2009).

2. Avahan - the India AIDS initiative. The business of HIV prevention at scale. New Delhi: Bill \& Melinda Gates Foundation, 2008. http://www.gatesfoundation.org/ avahan/Documents/Avahan HIVPrevention.pdf.

3. Moses S, Ramesh BM, Nagelkerke NJ, et al. Impact of an intensive HIV prevention programme for female sex workers on HIV prevalence among antenatal clinic attenders in Karnataka state, south India: an ecological analysis. AIDS 2008;22 (Suppl 5):S101-8.

4. Vickerman P, Foss AM, Pickles $\mathrm{M}$, et al. Is the Indian HIV epidemic driven by commercial sex? A modelling analysis from south India. 18th ISSTDR: 28 June-1 July 2009, London. http://www.isstdrlondon2009.com.

5. Chandrasekaran P, Dallabetta G, Loo V, et al. Evaluation design for large-scale HIV prevention programmes: the case of Avahan, the India AIDS initiative. AIDS 2008;22 (Suppl 5):S1-15.

6. Boily MC, Lowndes C, Alary M. The impact of HIV epidemic phases on the effectiveness of core group interventions: insights from mathematical models. Sex Transm Infect 2002;78(Suppl 1):i78-90.
7. Garnett GP, Gregson S, Stanecki KA. Criteria for detecting and understanding changes in the risk of HIV infection at a national level in generalised epidemics. Sex Transm Infect 2006;82(Suppl 1)::48-51.

8. Boily MC, Lowndes CM, Vickerman P, et al. Evaluating large-scale HIV prevention interventions: study design for an integrated mathematical modelling approach. Sex Transm Infect 2007:83:582-9.

9. Bradley JE, Moses S, Blanchard J, et al. Assessing reported condom use among female sex workers in southern India through examination of condom availability. Sex Transm Infect 2010;86(Suppl 1):i44-8.

10. Ramesh BM, Moses S, Washington R, et al. Determinants of HIV prevalence among female sex workers in four south Indian states: analysis of cross-sectional surveys in twenty-three districts. AIDS 2008;22(Suppl 5):S35-44.

11. Census of India. 2001. http://www.censusindia.net (accessed 19 May 2008)

12. Deering KN, Blanchard J, Moses S, et al. Characterising the factors associated with the numbers of client partners of female sex workers in south India: a geographic comparison. 18th ISSTDR; 28 June-1 July 2009, London. http://www. isstdrlondon2009.com

13. Rottingen JA, Cameron DW, Garnett GP. A systematic review of the epidemiologic interactions between classic sexually transmitted diseases and HIV: how much really is known? Sex Transm Dis 2001:28:579-97.

14. Foss AM, Vickerman PT, Chalabi Z, et al. Dynamic modeling of herpes simplex virus type-2 (HSV-2) transmission: issues in structural uncertainty. Bull Math Biol 2009;71:720-49.

15. Garnett GP, Aral SO, Hoyle DV, et al. The natural history of syphilis. Implications for the transmission dynamics and control of infection. Sex Transm Dis 1997:24:185-200.

16. Korenromp EL, Sudaryo MK, de Vlas SJ, et al. What proportion of episodes of gonorrhoea and chlamydia becomes symptomatic? Int J STD AIDS 2002;13:91-101.

17. Cheong WK, Thirumoorthy T, Doraisingham S, et al. Clinical and laboratory study of first episode genital herpes in Singapore. Int J STD AIDS 1990;1:195-8.

18. Corey L, Adams HG, Brown ZA, et al. Genital herpes simplex virus infections: clinica manifestations, course, and complications. Ann Intern Med 1983;98:958-72.

19. Corey L, Fife KH, Benedetti JK, et al. Intravenous acyclovir for the treatment of primary genital herpes. Ann Intern Med 1983;98:914-21.

20. Corey L, Wald A. Genital herpes. Holmes KK, Mardh PA, Sparling PF, et al, eds. Sexually transmitted diseases. 3rd ed. New York: McGraw-Hill, 1999: 285-312.

21. Diamond C, Selke S, Ashley R, et al. Clinical course of patients with serologic evidence of recurrent genital herpes presenting with signs and symptoms of first episode disease. Sex Transm Dis 1999;26:221-5.

22. Koelle DM, Benedetti J, Langenberg A, et al. Asymptomatic reactivation of herpes simplex virus in women after the first episode of genital herpes. Ann Intern Med 1992;116:433-7.

23. Guinan ME, MacCalman J, Kern ER, et al. The course of untreated recurrent genita herpes simplex infection in 27 women. N Engl J Med 1981;304:759-63.

24. Benedetti JK, Zeh J, Corey L. Clinical reactivation of genital herpes simplex virus infection decreases in frequency over time. Ann Intern Med 1999;131:14-20.

25. Wald A, Corey L, Cone R, et al. Frequent genital herpes simplex virus 2 shedding in immunocompetent women. Effect of acyclovir treatment. J Clin Invest 1997:99:1092-7.

26. Wald A, Zeh J, Selke S, et al. Genital shedding of herpes simplex virus among men $J$ Infect Dis 2002;186(Suppl 1):S34-9.

27. Wald A, Zeh J, Selke S, et al. Reactivation of genital herpes simplex virus type 2 infection in asymptomatic seropositive persons. N Engl J Med 2000;342:844-50.

28. Benedetti J, Corey L, Ashley R. Recurrence rates in genital herpes after symptomatic first-episode infection. Ann Intern Med 1994;121:847-54.

29. Lafferty WE, Coombs RW, Benedetti J, et al. Recurrences after oral and genital herpes simplex virus infection. Influence of site of infection and viral type. $N$ Engl J Med 1987;316:1444-9.

30. Kim HN, Wald A, Harris J, et al. Does frequency of genital herpes recurrences predict risk of transmission? Further analysis of the valacyclovir transmission study. Sex Transm Dis 2008;35:124-8.

31. Schacker T, Zeh J, Hu HL, et al. Frequency of symptomatic and asymptomatic herpes simplex virus type 2 reactivations among human immunodeficiency virusinfected men. J Infect Dis 1998;178:1616-22.

32. Conant MA, Schacker TW, Murphy RL, et al. Valaciclovir versus aciclovir for herpes simplex virus infection in HIV-infected individuals: two randomized trials. Int J STD AIDS 2002;13:12-21.

33. Grover G, Shivraj SO. Survival pattern of reported HIV infected individuals in the city of Delhi (India). J Commun Dis 2004;36:83-92.

34. Kumarasamy N, Solomon S, Flanigan TP, et al. Natural history of human immunodeficiency virus disease in southern India. Clin Infect Dis 2003;36:79-85.

35. Boily MC, Baggaley RF, Wang L, et al. Heterosexual risk of HIV-1 infection per sexual act: systematic review and meta-analysis of observational studies. Lancet Infect Dis 2009;9:118-29.

36. Wawer MJ, Gray RH, Sewankambo NK, et al. Rates of HIV-1 transmission per coita act, by stage of HIV-1 infection, in Rakai, Uganda. J Infect Dis 2005;191:1403-9.

37. Wald $\mathbf{A}$, Langenberg AG, Link K, et al. Effect of condoms on reducing the transmission of herpes simplex virus type 2 from men to women. JAMA 2001;285:3100-6.

38. Corey L, Wald A, Patel R, et al. Once-daily valacyclovir to reduce the risk of transmission of genital herpes. N Engl J Med 2004;350:11-20.

39. Wald A, Huang ML, Carrell D, et al. Polymerase chain reaction for detection of herpes simplex virus (HSV) DNA on mucosal surfaces: comparison with HSV isolation in cell culture. J Infect Dis 2003;188:1345-51. 
40. Holmes KK, Johnson DW, Trostle HJ. An estimate of the risk of men acquiring gonorrhea by sexual contact with infected females. Am J Epidemiol 1970;91:170-4.

41. Mertz GJ, Schmidt 0, Jourden JL, et al. Frequency of acquisition of first-episode genital infection with herpes simplex virus from symptomatic and asymptomatic source contacts. Sex Transm Dis 1985;12:33-9.

42. Nagot N, Ouedraogo A, Foulongne V, et al. Reduction of HIV-1 RNA levels with therapy to suppress herpes simplex virus. N Engl J Med 2007;356:790-9.

43. Zuckerman RA, Lucchetti A, Whittington WL, et al. Herpes simplex virus (HSV) suppression with valacyclovir reduces rectal and blood plasma HIV-1 levels in HIV-1/HSV-2-seropositive men: a randomized, double-blind, placebo-controlled crossover trial. J Infect Dis 2007;196:1500-8.

44. Baeten JM, Strick LB, Lucchetti A, et al. Herpes simplex virus (HSV)-suppressive therapy decreases plasma and genital HIV-1 levels in HSV-2/HIV-1 coinfected women: a randomized, placebo-controlled, cross-over trial. J Infect Dis 2008;198:1804-8.

45. Celum C, Wald A, Hughes J, et al. Effect of aciclovir on HIV-1 acquisition in herpes simplex virus 2 seropositive women and men who have sex with men: a randomised, double-blind, placebo-controlled trial. Lancet 2008:371:2109-19.

46. Dunne EF, Whitehead S, Sternberg M, et al. Suppressive acyclovir therapy reduces HIV cervicovaginal shedding in HIV- and HSV-2-infected women, Chiang Rai, Thailand. J Acquir Immune Defic Syndr 2008:49:77-83.

47. Delany S, Mlaba N, Clayton T, et al. Impact of aciclovir on genital and plasma HIV-1 RNA in HSV-2/HIV-1 co-infected women: a randomized placebo-controlled trial in South Africa. AIDS 2009;23:461-9.

48. Schacker T, Hu HL, Koelle DM, et al. Famciclovir for the suppression of symptomatic and asymptomatic herpes simplex virus reactivation in HIV-infected persons. A double-blind, placebo-controlled trial. Ann Intern Med 1998;128:21-8.

49. Mbopi-Keou FX, Gresenguet G, Mayaud P, et al. Interactions between herpes simplex virus type 2 and human immunodeficiency virus type 1 infection in African women: opportunities for intervention. J Infect Dis 2000;182:1090-6.

50. Augenbraun M, Feldman J, Chirgwin K, et al. Increased genital shedding of herpes simplex virus type 2 in HIV-seropositive women. Ann Intern Med 1995; 123:845-7.

51. Nagot N, Foulongne V, Becquart $\mathrm{P}$, et al. Longitudinal assessment of HIV-1 and HSV-2 shedding in the genital tract of West African women. J Acquir Immune Defic Syndr 2005;39:632-4.

52. LeGoff J, Weiss HA, Gresenguet G, et al. Cervicovaginal HIV-1 and herpes simplex virus type 2 shedding during genital ulcer disease episodes. AIDS 2007;21:1569-78.

53. Serwadda D, Gray RH, Sewankambo NK, et al. Human immunodeficiency virus acquisition associated with genital ulcer disease and herpes simplex virus type 2 infection: a nested case-control study in Rakai, Uganda. J Infect Dis 2003;188:1492-7.

54. Nagot N, Ouedraogo A, Konate I, et al. Roles of clinical and subclinical reactivated herpes simplex virus type 2 infection and human immunodeficiency virus type 1 (HIV-1)-induced immunosuppression on genital and plasma HIV-1 levels. J Infect Dis 2008;198:241-9.

55. Quinn TC, Wawer MJ, Sewankambo N, et al. Viral load and heterosexua transmission of human immunodeficiency virus type 1. Rakai Project Study Group. N Engl J Med 2000;342:921-9.

56. Corey L, Wald A, Celum CL, et al. The effects of herpes simplex virus-2 on HIV-1 acquisition and transmission: a review of two overlapping epidemics. J Acquir Immune Defic Syndr 2004:35:435-45.

57. Freeman EE, Weiss HA, Glynn JR, et al. Herpes simplex virus 2 infection increases HIV acquisition in men and women: systematic review and meta-analysis of longitudinal studies. AIDS 2006;20:73-83.
58. Watson-Jones D, Weiss HA, Rusizoka M, et al. Effect of herpes simplex suppression on incidence of HIV among women in Tanzania. N Engl J Med 2008;358:1560-71.

59. Pinkerton SD, Abramson PR, Turk ME. Updated estimates of condom effectiveness. J Assoc Nurses AIDS Care 1998;9:88-9.

60. Pinkerton SD, Abramson PR. Effectiveness of condoms in preventing HIV transmission. Soc Sci Med 1997:44:1303-12.

61. Wald A, Langenberg AG, Krantz E, et al. The relationship between condom use and herpes simplex virus acquisition. Ann Intern Med 2005;143:707-13.

62. Oberle MW, Rosero-Bixby L, Lee FK, et al. Herpes simplex virus type 2 antibodies: high prevalence in monogamous women in Costa Rica. Am J Trop Med Hyg 1989:41:224-9.

63. Dobbins JG, Mastro TD, Nopkesorn T, et al. Herpes in the time of AIDS: a comparison of the epidemiology of HIV-1 and HSV-2 in young men in northern Thailand. Sex Transm Dis 1999;26:67-74.

64. Obasi A, Mosha F, Quigley M, et al. Antibody to herpes simplex virus type 2 as a marker of sexual risk behavior in rural Tanzania. J Infect Dis 1999;179:16-24.

65. Huerta K, Berkelhamer S, Klein J, et al. Epidemiology of herpes simplex virus type 2 infections in a high-risk adolescent population. J Adolesc Health 1996;18:384-6.

66. Holmes KK, Levine R, Weaver M. Effectiveness of condoms in preventing sexually transmitted infections. Bull World Health Organ 2004:82:454-61.

67. Hooper RR, Reynolds GH, Jones OG, et al. Cohort study of venereal disease. I: the risk of gonorrhea transmission from infected women to men. Am J Epidemiol 1978:108:136-44.

68. Austin H, Louv WC, Alexander WJ. A case-control study of spermicides and gonorrhea. JAMA 1984;251:2822-4

69. Barlow D. The condom and gonorrhoea. Lancet 1977:2:811-13.

70. Joesoef MR, Linnan M, Barakbah Y, et al. Patterns of sexually transmitted diseases in female sex workers in Surabaya, Indonesia. Int J STD AIDS 1997:8:576-80.

71. Sanchez J, Campos PE, Courtois B, et al. Prevention of sexually transmitted diseases (STDs) in female sex workers: prospective evaluation of condom promotion and strengthened STD services. Sex Transm Dis 2003:30:273-9.

72. Gaydos CA, Howell MR, Pare B, et al. Chlamydia trachomatis infections in female military recruits. N Engl J Med 1998;339:739-44.

73. Niccolai LM, Rowhani-Rahbar A, Jenkins $\mathrm{H}$, et al. Condom effectiveness for prevention of Chlamydia trachomatis infection. Sex Transm Infect 2005;81:323-5.

74. Zenilman JM, Weisman CS, Rompalo AM, et al. Condom use to prevent incident STDs: the validity of self-reported condom use. Sex Transm Dis 1995:22:15-21.

75. Lowndes C, Alary M, Verma S, et al. Assessment of intervention outcome in the absence of baseline data: 'reconstruction' of condom use time trends using retrospective in analysis of survey data. Sex Transm Infect 2010;86:i49-55.

76. Weiss G, von Haeseler A. Inference of population history using a likelihood approach Genetics 1998:149:1539-46.

77. Vickerman P, Platt L, Hawkes S. Modelling the transmission of HIV and HCV among injecting drug users in Rawalpindi, a low HCV prevalence setting in Pakistan. Sex Transm Infect 2009:85(Suppl 2):ii23-30.

78. Hallett TB, Gregson S, Mugurungi 0 , et al. Assessing evidence for behaviour change affecting the course of HIV epidemics: a new mathematical modelling approach and application to Zimbabwe. Epidemics 2009;1:108-17.

79. Karnataka Health Promotion Trust. About BIRDS. http://www.khpt.org/birds.htm (accessed 15 July 2009).

80. Boily MC, Pickles M, Vickerman $\mathrm{P}$, et al. Using mathematical modelling to investigate the plausibility of attributing observed antenatal clinic declines to a female sex worke intervention in Karnataka state, India. AIDS 2008-22(Suppl 5):S149-64. 